\title{
CAPERUCITA EN EL BOSQUE WEB: DEL MITO A LA CREACIÓN HIPERBREVE (CON UNA VUELTA DE TUERCA POLÍTICA)
}

\author{
Carmen Morán Rodríguez \\ Universidad de Valladolid \\ carmen.moran@uva.es
}

Resumen: Aunque conocemos la historia de Caperucita Roja a través de versiones literarias (principalmente las de Perrault y los hermanos Grimm), la fortuna de este cuento sobre otros y la concurrencia en él de numerosos mitemas permite emparentarlo con el mito en tanto que explicación no racional sobre alguna cuestión concerniente a la existencia humana. La ficción contemporánea ofrece numerosas versiones y revisiones de la historia. El microrrelato en lengua española es uno de los géneros en que más ejemplos podemos encontrar, y, en las últimas décadas, Internet se ha convertido en el espacio donde la fecundidad es más acusada. En el artículo analizaremos varios ejemplos de ficción hiperbreve (en las formas exocanónicas de viñetas y memes) que revelan la vigencia del mito, más allá de la ficción, para canalizar las preocupaciones de una comunidad - preocupaciones que hoy, en buena medida, son políticas-.

Palabras clave: mito, cuento popular, cuento tradicional, Caperucita, ficción hiperbreve

\section{LITTLE RED RIDING THE WEB: FROM MYTH TO FLASH FICTION AND MEMES (WITH A POLITICAL TURN OF THE SCREW)}

\begin{abstract}
We know the tale of Little Red Riding Hood through literary versions, mainly those of Perrault $y$ the Brothers Grimm. But it involves many mythemes and, as a matter of fact, can be considered itself as a myth that became a tale, still keeping elements from a non-rational explanation of some questions concerning human being. Contemporary fiction offers many versions of the tale, challenging the old tale and giving new meanings to it. Many examples are provided by microfiction in Spanish. Within the last two decades, Internet has become the arena where these microfictions have been shared and viralized, and now they live together with Twitter-born stories, fan art, etc. In our paper we analyze some intermedia works (memes and cartoons) where Little Red Riding Hood, the most popular folktale, expresses political ideas bound to news.
\end{abstract}

Keywords: Myth, Folktale, Flash fiction, Little Red Riding Hood, Fanfiction, Fan art

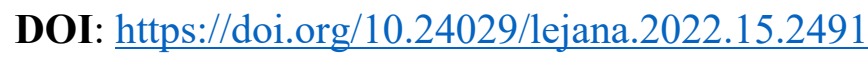

Recibido: 1 de septiembre de 2021

Aceptado: 29 de noviembre de 2021

Publicado: 25 de febrero de 2022 
Aunque la reescritura de los cuentos tradicionales no se ha detenido nunca - de hecho, las versiones consideradas "canónicas" o incluso llamadas a veces "originales" no son sino eslabones particularmente afortunados de esa cadena de reescrituras—-, desde los años 60 del pasado siglo proliferaron las versiones que proponían subversiones de los cuentos clásicos. ${ }^{1}$ Primero en el mundo anglosajón —Angela Carter es el ejemplo más sobresaliente- y más tarde en otros idiomas, las (per)versiones de cuentos clásicos tradicionales se multiplicaron en las décadas siguientes: podemos citar, como cultivadores de estos nuevos cuentos de hadas, al polaco Slawomir Mrozek, el estadounidense James Finn Garner o — en la estela de Carter y con una clara inclinación feminista - las españolas Carmen Martín Gaite y Ana María Matute, seguidas por Quim Monzó o Gustavo Martín Garzo. Contamos ya con una extensa bibliografía que se ha encargado más de identificar los motivos y las transformaciones operadas sobre ellos que de trazar el mapa de conexiones entre todos estos narradores del cuento tradicional posmoderno (Bacchilega 1997, 2013; AA.VV. 2011; García Puente 2014; Morán Rodríguez 2018, por citar solo trabajos que no se ciñen a un único cuento o motivo en particular). En este panorama, el cuento breve e hiperbreve han resultado ser un vehículo especialmente fecundo, y aunque no faltan en otras lenguas (como Gilbert Lascault en francés), son las autoras hispanoamericanas las que desde los años 70 han cultivado de modo sobresaliente esta reescritura de cuentos tradicionales en formato breve. La brevedad, concebida como rasgo constitutivo fundamental del relato, ha ido acentuándose con el tiempo, y tiene el efecto de intensificar el carácter intertextual, interconectado y relativo propio de una forma de creación que se sabe siempre parte de un todo potencialmente infinito, la tradición. Como es obvio, Internet ha incrementado extraordinariamente las posibilidades de difusión del formato hiperbreve y de la interacción textovisual y texto-audiovisual, dando lugar a una ingente y heterogénea producción que demanda nuestro análisis.

Dentro del vasto y discutible canon de los cuentos tradicionales universales, ninguno puede disputar a la humilde Caperucita su condición de reina (Ritz, 2000: 7). Su arraigo en nuestro imaginario no parece solo indicio de que este cuento es material compartido, consabido por su reiteración a lo largo de los siglos, y por tanto referente intertextual ampliamente reconocible. Más bien habrá que suponer que esa vigencia obedece a la capacidad de este cuento en particular para canalizar preocupaciones humanas que persisten al cabo de los siglos, o bien (pero ambas posibilidades no se excluyen necesariamente) para mutar, resemantizándose a fin de dar cauce, sucesivamente, a problemas que cambian en su forma, pero cuyo trasfondo mantiene lo esencial. Eso explicaría por qué Caperucita supera en vigencia a otras figuras del cuento tradicional, incluidas las muy populares Blancanieves, Cenicienta o la Bella Durmiente - y ello a pesar de no haber sido fijada en el canon contemporáneo a través de un largometraje de Disney, a diferencia de lo que sucede con las anteriores-. ${ }^{2}$ Ritz se pregunta por los motivos que hacen de este cuento el más apto para

\footnotetext{
${ }^{1}$ Este artículo se ha realizado en el marco de las actividades del proyecto de Investigación Fractales. Estrategias para la fragmentación en la narrativa española del siglo XXI (PID2019-104215GB-I00), financiado por el Ministerio de Ciencia e Innovación. Asimismo, forma parte de las investigaciones desarrolladas por el Grupo de Investigación Reconocido Literatura Española Contemporánea (Universidad de Valladolid) y el Grupo de Investigación Consolidado MiRed (Universidad San Pablo CEU).

${ }^{2}$ Caperucita sí aparece en un cortometraje titulado The Big Bad Wolf (1934), del ciclo Silly Symphonies, producido por Walt Disney y dirigido por Burt Gillet. La popularidad de esta pequeña pieza no puede
} 
adaptarse a cada época convirtiéndose en "su espejo" (Ritz, 2020: 7), pero su respuesta, al señalar que se trata del más bello, el más popular, conocido y variado de los cuentos tradicionales (7), no deja de ser tautológica. Tenemos razones para suponer que es algo más que belleza o la popularidad lo que explica su duradera vitalidad, y ese algo es su pertenencia no al ámbito estricto de la ficción, sino al del mito. Caperucita no nos cuenta una historia intercambiable por cualquier otra, sino que recurre a una historia universal y actualizable para hablarnos de verdades esenciales que se filtran a través de un apretado ramillete de motivos, como han estudiado ya, entre otros, Zipes (1983), Dundes (1989), Ziolkowski (1992) o González Marín (2005).

No es este el lugar para trazar el complejo recorrido de Caperucita en la literatura y las artes, tarea sin fin pero necesaria, a la que han contribuido notablemente Beckett $(2002,2008)$ y Orenstein (2003), entre otros. En el relato breve hispanoamericano, Ana María Shua y Luisa Valenzuela abrirán el camino, creando a su vez una tradición a partir de la tradición. Noguerol Jiménez analizó los giros que en sus microficciones Shua imprime a lo conocido (2000), así como el relato "Si esto es la vida, yo soy Caperucita Roja", de Luisa Valenzuela (2001). Observaba en este último caso Noguerol un "interesante proceso de licantropización" por el que la niña protagonista no solo no necesitaba de la ayuda de un leñador para vencer al lobo, sino que ni siquiera deseaba hacerlo, pues ella misma asumía "su ferocidad interior", reconociéndose loba (Noguerol Jiménez 2001). ${ }^{3}$

En un trabajo de 2019, Martínez Deyros analiza varias microhistorias basadas en el personaje de Caperucita de autores tan diversos como Javier Tomeo, Blanca de Queta Navagómez, Juan Armando Epple, Lilian Elphick o Yolanda Izard. Todos ellos subvierten las versiones tradicionales, aunque por diferentes caminos. El estudio incluye también caperucitas ya específicamente creadas y divulgadas en el ámbito de la web: así las brevísimas reescrituras del ciclo "Caperucita tuiteada" de José Luis Zárate, o las que Patricia Esteban Erlés publica a través de la red social Facebook como glosa de una imagen encontrada en Internet. Martínez Deyros presta asimismo atención a las recreaciones ideadas por ilustradores como Sergio Astorga (para Elphick), Abraham Morales (para Zárate) o Quique Ortega.

Todas estas versiones conviven, en el amplio espacio de Internet, con otras muchísimas que atestiguan la enorme difusión del personaje y la historia en la cultura popular,

compararse con la de los largometrajes canónicos de Disney —en los que el protagonismo recae sobre una "princesa" que, al menos en la versión Disney, ha dejado definitivamente atrás la infancia y aparece invariablemente como pareja romántica de un joven-. The Big Bad Wolf, además, no es una adaptación de la historia fijada por Perrault, sino una refundición en que la niña de la capa roja se cruza con los tres cerditos y juntos deben hacer frente al animal enemigo que, entre otras artimañas, se disfraza de Goldilocks the Fairy Queen, es decir, "Ricitos de Oro el hada del bosque" — aumentando los referentes implicados en la interpolación, aunque no su motivación en la historia, que se reduce al mínimo-.

${ }^{3}$ Esta licantropización se advierte también en el desenlace del film The Company of Wolves (1984), dirigida por Neil Jordan a partir de un guion escrito en colaboración entre Angela Carter y Jordan. La película —excelentesubraya los aspectos sexuales de la versión de Perrault y la interpretación de Bettelheim, pero también gira en torno a la excesiva represión que la cultura (en el sentido amplio de comportamiento social, y específicamente en el comportamiento pautado por directrices religiosas) impone sobre todo lo natural (incluido el sexo). Posteriormente, la película Wolf (1994, dirigida por Mike Nichols), mucho menos estimulante desde el punto de vista artístico y narrativo, optó también por un desenlace "licantropizador", que rompe la identificación entre el ser humano y el bien y el lobo y el mal. 
entendiendo por "cultura popular" aquella acanónica, no hegemónica, bullente al margen de la literatura "de los cultos". Se nutre de Perrault, de Grimm o de cualquiera de las versiones literarias aquí mencionadas y otras muchas, así como de sus versiones cinematográficas, televisivas, publicitarias o pornográficas, expandiendo un fenómeno estudiado por Orenstein (2003). Me refiero ahora a productos del fan art, memes y dibujos inspiracionales que proliferan en la red, a un tiempo renuentes a categorizaciones y cargados de etiquetas, por paradójico que pueda parecer. Irrelevantes unas veces, ingeniosos otras, zafios o sutiles, a su vez alimentan nuevas versiones. ${ }^{4}$

Buena parte de las apariciones de la niña con la capa roja en la ciberesfera entran dentro del dominio del fan art, con predominio de la imagen sobre el texto, reducido a un pie de página con escasa proyección narrativa. No faltan memes que simplemente inciden sobre los elementos menos verosímiles de la versión de Perrault o sobre otros elementos como detonantes de humor absurdo. Son muy frecuentes las recreaciones de Caperucita y el lobo adaptados a una estética grimdark (caracterizada por los elementos de violencia y agresividad y la frecuente mezcla de tecnología y monstruosidad fantasiosa); también las variaciones que acentúan el erotismo, verdaderamente ya cosustancial a varios de los motivos articulados en torno al relato de la niña que se encuentra al lobo en el camino del bosque. En estas estampas lo verbal brilla por su ausencia o, en todo caso, no da pie a un desarrollo narrativo, sino a una mínima reinterpretación del sentido de la historia. La carga erótica de la imagen no obsta que el sentido de ese subtítulo pueda ser feminista, a partir de un empoderamiento del mensaje sexual implícito en tantas versiones del cuento (FIGURAS 2, 3 y 4), de una inversión posmoderna de los valores del amor romántico, en la línea de lo que los cuentos de Shua o Valenzuela ya habían hecho (las anteriores, especialmente la FIGURA 4), o de la resignificación de la iconografía sexy (que, pese a la pretendida reinterpretación feminista, en ocasiones no va más allá de la recreación de esa misma iconografía: FIGURA 3). No falta algún caso en que el icónico personaje sirve a otro mensaje político inesperado, como el derecho a llevar armas (FIGURA 5). Junto a estos ejemplos es posible encontrar otros más interesantes de los que aquí pretendo dejar muestra, y que manifiestan la capacidad del cuento para expresar tensiones y misterios — políticos, por qué no— vigentes en nuestra comunidad, hoy global.

El mito - explicación no racional para hechos ante los cuales la razón no ofrece una respuesta concluyente o satisfactoria ${ }^{5}$ puede encauzar un discurso político. Al remarcar el

\footnotetext{
4 El hecho de que estas, a su vez, lleguen a ser valoradas como obras singulares y no como meras manifestaciones de un fenómeno popular es cuestión que ahora queda fuera de nuestro objetivo.

${ }^{5}$ Establecer una definición del mito supone llevar a cabo una historia del término y el concepto tal y como lo abordan diferentes disciplinas (como la filosofía, la antropología o la historia de las religiones) y distintos enfoques (estructuralista, semiológico, etcétera). La aproximación de Buxton es tal vez intuitiva, pero sumamente iluminadora: "[...] we can see myth as a device for making explicit, for highlighting what is behind life. But, paradoxically, one of the aspects of the world made explicit in myths is the incompleteness of human understanding of the world, and the insufficiency of human models of behaviour for comprehending divinity" (1994: 78). Por su parte, Mircea Eliade propone el siguiente ensayo de definición: "el mito cuenta una historia sagrada; relata un acontecimiento que ha tenido lugar en el tiempo primordial, el tiempo fabuloso de los «comienzos». Dicho de otro modo: el mito cuenta cómo, gracias a las hazañas de los Seres Sobrenaturales, una realidad ha venido a la existencia, sea ésta la realidad total, el Cosmos, o solamente un fragmento: una isla, una especie vegetal, un comportamiento humano, una institución. Es, pues, siempre el relato de una «creación»: se narra cómo algo ha sido producido, ha comenzado a ser. El mito no habla de lo que ha sucedido realmente, de lo que se ha manifestado plenamente" (Eliade, 1991: 6).
} 
carácter etiológico del mito, solemos pensar que se aplica a misterios de la existencia (el nacimiento, el tiempo, la muerte, los sexos o las razas) o a fenómenos del universo (la lluvia, el ciclo vegetal). En las versiones anteriores al siglo XX, diferentes mitemas se articulaban para mostrar distintos aspectos sobre la tensión entre naturaleza y civilización, siendo el más visible de ellos el de la sexualidad. ${ }^{6}$ Pero eso no significa que el mito no pueda dar cauce también a mensajes cargados de un sentido político. En el siglo II d. C. el geógrafo lidio Pausanias se hace eco de una leyenda según la cual en la ciudad de Temesa un hombre cubierto de una piel de lobo habría violado a una doncella, pero no solo el sexo está presente en esta versión periférica de la constelación de caperucitas: tanto Elsner como González Marín ven en el relato de Pausanias un acto de resistencia política, la del escritor griego que hace frente al imperialismo romano, mediante la recopilación de leyendas con un valor identitario helénico (González Marín, 2005: 98-99). Es cierto que el posicionamiento político no estaría tanto en la historia, como con la actividad de Pausanias como compilador de tradiciones griegas, y tampoco podemos estar seguros de hasta qué punto la leyenda de la muchacha violada por un asaltante embozado en una piel de lobo era reconocida como parte de una constelación de historias y mitemas, o es interpretada así por nosotros a posteriori. Un ejemplo más indiscutible de politización podemos advertir en las caperucitas de Ludwig Tieck y de los Hermanos Grimm, relatos germánicos con importantes elementos de rechazo a lo francés (Gonzalez Marín, 2005: 37). La resemantización política del mito, en fin, alcanza un grado máximo en el ensayo nazi de Werner von Bulow sobe Caperucita roja (1937), en el film Rotkäppchen (dirigido en 1937 por Fritz Genschow y Renee Stobrawawhich), y en la versión anti-nazi debida a Ulrich Link (Zipes, 1983: 54-55); también en las muchas versiones infantiles que durante la posguerra española prefirieron el título Caperucita encarnada, para evitar, por sus connotaciones, el adjetivo "roja" (González Marín, 2005: 28).

En los últimos años, Internet ha sido el lugar en el que se ha creado y difundido un buen número de microficciones intermediales, viñetas o memes cuya narratividad descansa simultáneamente sobre lo gráfico y lo verbal, y que implican una lectura en clave política compartida por los receptores, a menudo anclada en sucesos de la actualidad para los que sigue siendo pertinente la respuesta poética que ofrece el mito. A grandes rasgos, será posible clasificar la mayor parte de estas recreaciones textovisuales de Caperucita con un sentido político en dos grupos: uno en el que la carga política se fundamenta sobre la oposición ideológica derechas/izquierdas (ligada al mito por las connotaciones del adjetivo "roja"), y otro marcado por el compromiso feminista, donde el elemento motivador sería el ataque del lobo sobre Caperucita, que ya en versiones antiguas se entendía como una metáfora de la violación o incluso del matrimonio como institución que sometía el asalto sexual a las leyes civilizadoras (González Marín, 2005: 72) —nuevamente, como vemos, la tensión entre cultura y naturaleza parece ser el trasfondo de este haz de historias-.

\footnotetext{
${ }^{6}$ Buena parte de las incontables narraciones y manifestaciones culturales que pueden encontrar amparo bajo la denominación general "Caperucita roja" escenifica la oposición entre civilización y naturaleza, manifestada a través de varios mitemas, no todos ellos presentes en todas las versiones: la oposición entre el sendero y el bosque, entre los ropajes y la desnudez, entre el canibalismo y la comida cocinada a partir de cereales, y entre la defecación en el lugar donde se vive o fuera de él, oposiciones todas ellas relacionadas con tabúes que se identifican con estratos de cultura o "civilización" (Morán Rodríguez, en prensa).
} 
Antes de identificar y comentar algunos de esos ejemplos, es pertinente señalar que, desde hace décadas, en el humor gráfico contábamos con ejemplos de recreaciones textovisuales basadas en el intertexto de Caperucita - aclararé que manejo únicamente, de momento, ejemplos españoles-. A falta de un trabajo que identifique la revisión del cuento infantil en este campo creativo, destacaremos a uno de sus mejores representantes, Antonio Fraguas de Pablo "Forges" (1942-2018), quien participa en un "Comiciclo" (ciclo de cómics) de varios autores. Él firma, entre otros, cuatro volúmenes dedicados a Caperucita Roja, bajo el título general de Caperucita roja, con perdón, que englobaba "Caperucita propiamente dicha", "El lobo blue", "Simplemente abuelita" y "Desenlace fatal". En el mismo ciclo participó también otro conocido viñetista, Chumy Chúmez, con "Blancanieves y los siete enanitos" y "La bella democracia durmiente del bosque". Forges empleará el reconocible subtexto en otras viñetas: si observamos las FIGURAS 6 y 7, veremos que, en la primera, más antigua, publicada en Hermano Lobo, ${ }^{7}$ el resorte humorístico es el cambio en los tiempos y en la juventud, motivo que en los años de la Transición democrática era de gran actualidad, pero que en la viñeta no se carga de un sentido político explícito; la segunda, en cambio, posterior (apareció en el diario El País el 2 de julio de 2008), sí lo hay. En ella observamos a Caperucita, que es en realidad "Fernández", oficinista insignificante - tipo tantas veces inmortalizado por Forges - que trata de pasar desapercibido, bajo su capita roja, ante el enorme y trajeado señor que le corta el camino, y que "solo es el jefe de recursos humanos del bosque": la fábula que Perrault empleó para aleccionar a las jovencitas ante el riesgo de caer en los brazos de los seductores sirve ahora para representar la desproporción de fuerzas entre el trabajador y los abusivos representantes de la patronal y el orden económico. La ingenuidad naif del subtexto y la comicidad del oficinista Fernández, con su bigote, travestido de Caperucita, subraya precisamente el cariz abusivo imperante en el "Proceloso bosque laboral" (ese es el título de la viñeta), que es lo que se pretende denunciar. No perdamos de vista que, en el verano de 2008, cuando la crisis económica arreciaba, se iniciaron las negociaciones para una reforma laboral que finalmente se aprobaría (no sin polémicas) en 2010.

Es posible pues - y un trabajo por hacer- rastrear las reescrituras políticas de este cuento en el humor gráfico en español del siglo $\mathrm{XX}$, especialmente en su último tercio, considerando que forma un acervo que es posible relacionar a varios niveles con las creaciones que hoy circulan por la Red: en primer lugar, porque, incluso aunque no haya un conocimiento directo de esos ejemplos pioneros del humor gráfico de la posguerra, el uso de los mismos motivos y mitemas suscita interesantes coincidencias y divergencias; en segundo lugar, porque autores como Forges o Chumy Chúmez han sido referentes para viñetistas actuales cuyas obras se difunden masivamente en Internet, cuando no se crean expresamente para las redes sociales. ${ }^{8}$

\footnotetext{
${ }^{7}$ La revista satírica Hermano Lobo fue fundada en 1972 por José Ángel Ezcurra, y se publicó hasta junio de 1976, hasta un total de 276 números. Contó con colaboradores como Forges, Chumy Chúmez, Quino, Gila, El Roto, Manuel Vázquez Montalbán o Francisco Umbral.

${ }^{8}$ De hecho, en este trabajo tomamos como corpus ejemplos que circulan en Internet, independientemente de que el medio original de publicación sea prensa digital (como el diario El Español), una red social directamente utilizada por el autor para la difusión de su trabajo (Tumblr, en el caso de Ferrán Martín) o los perfiles en redes sociales de publicaciones en papel que, como El Jueves o Mongolia, cada vez emplean más Twitter y Facebook como medios complementarios de difusión y promoción (hasta el punto de que la publicación en papel termina siendo casi testimonial respecto de la difusión digital).
} 
En los últimos años, hemos visto proliferar en los medios de comunicación y las redes sociales titulares, viñetas y memes alusivos a Caperucita Roja con sentidos claramente políticos, gran parte de los cuales giran en torno al tropo "roja", uno de los más persistentes entre los que se combinan en la composición del cuento dentro del imaginario popular. ${ }^{9}$ Con todo, aunque la mayoría basan su significación pragmática en el sentido figurado de "roja", es posible encontrar algún ejemplo que se desvía de esta tendencia. Así, la viñeta del 21 de julio de 2016 de J. M. Nieto para $A B C$ (FIGURA 8). El elemento sobre el que pivota la viñeta es el lobo, aquí molesto por la etiqueta "lobo solitario" (que sin ser nueva ha proliferado en la prensa al ritmo al que lo hacían los atentados perpetrados por criminales no pertenecientes a ninguna organización armada). El sintagma, parece decirnos Nieto, mancilla el nombre del "malo del cuento" con una nueva maldad inusitada; así lo confirma el subtítulo "En defensa del lobo". El asunto era de actualidad, ya que unos días antes (el 18 de julio de 2016) un somalí de 24 años y sin motivaciones claras había herido a varios ciudadanos con un cuchillo; numerosos medios de comunicación calificaron al atacante de "lobo solitario". La viñeta también puede apuntar satíricamente a la sensibilidad exacerbada de colectivos que se sienten ofendidos por alusiones figuradas. Nieto, por cierto, recurre de nuevo a Caperucita y el lobo para abordar el mismo asunto en otra viñeta del 4 de junio de $2013 .^{10}$

La viñeta firmada por Padylla (figura 9), con el título "Caperucita muy roja" muestra a una abuela en la que son reconocibles los rasgos de Pablo Iglesias, secretario general del partido izquierdista español Podemos, caracterizado como lobo travestido de abuela; ante él, una Caperucita que porta una papeleta de voto hace notar, parafraseando la conocida fórmula, “Alberto Garzón, qué coleta más grande tienes". La viñeta, publicada en mayo de 2016, alude a la sustitución de Garzón, el candidato de Izquierda Unida, por Iglesias, candidato de Unidas Podemos, coalición en la que se integró (o desintegró) la formación izquierdista anterior.

Otra viñeta, más reciente, es la firmada por el ilustrador Maikel en el semanario satírico El Jueves, tuiteada el 9 de noviembre de 2018, como reto para los lectores de la red social que quisieran completarla con un texto, bajo el título "¿Qué le dice el lobo a Caperucita Sánchez?". En el dibujo de Maikel, de la boca del lobo salía, en efecto, un bocadillo en blanco aguardando a ser escrito. El meme seleccionado, con texto de Marc LM (@mmaclopez), alude al vaciamiento ideológico operado en el PSOE. En ella (FIGURA 10) vemos a un desconcertado lobo plantado ante Caperucita (en realidad, el candidato socialista a la presidencia española Pedro Sánchez, ataviado con la consabida capa roja). Con rostro desconcertado, el feroz animal afirma que no encuentra en la cestita nada "de izquierdas" que llevarse a la boca. La viñeta recibió algunas respuestas ingeniosas, como la de (a)lurkerinthebits, que siguiendo el juego intertextual remataba "Qué promesas tan grandes tienes!". El travestismo (reforzado por la exagerada sonrisa con que se representa a Sánchez) aludiría aquí a las estrategias de retórica electoralista que ocultarían, dejándolas en un plano secundario, las medidas concretas esperables en un programa.

\footnotetext{
${ }^{9}$ Otros, como el pastelillo o panecillo portado en la cesta, no son tan relevantes, aunque podamos interpretarlos como trazas elocuentes de la filiación antigua, con impronta religiosa y ritual, del relato (véase a este respecto González Marín, 2005).

${ }^{10}$ https://abcblogs.abc.es/fe-de-ratas/vinetas/lobos-solitarios-yihadistas-por-j-m-nieto.html.
} 
Si bien el sentido metafórico de "roja" como "izquierdista" es la motivación básica que propicia el desarrollo de ambos ejemplos, también vemos que ambos sacan partido de otro componente singular del relato: el travestismo. La primera lo hace en la escena que la tradición ha reservado a la suplantación de la abuela, cuando el lobo aguarda a Caperucita vestido con las ropas de la vieja, y se dirige a ella impostando la voz, y logrando engañarla, al menos hasta el desenlace del célebre diálogo. La inverosimilitud de esta escena a la luz de un horizonte de expectativas de la ficción moderna ha sido jocosamente resaltada a menudo (por ejemplo, en otro meme de circulación común: véase FIGURA 1). Tal inverosimilitud, sin embargo, corre parejas al magnetismo del pasaje: como afirmó Djuna Barnes, "Los niños sienten algo que no pueden decir: ¡les gusta que el lobo y Caperucita estén en la cama!" (cit. en Bettelheim, 1994: 208).

La segunda viñeta comentada, por el contrario, opta por otro momento crucial del cuento: el encuentro de Caperucita y el lobo en el bosque, adelantando y desplazando el travestismo, que ahora no está directamente anclado al del cuento, sino que descansa sobre una motivación más lasa (la sustitución de la protagonista por un candidato político ataviado simplemente por la capa roja). Son incontables las reformulaciones que apelan intertextualmente a cuentos de la tradición, sustituyendo a la protagonista (habitualmente femenina) por otro personaje, a veces de la actualidad, con intención a menudo cómica. Pero en el caso de Caperucita, por más que se diluya, el engaño con la identidad forma parte intrínseca del cuento. Cómo no recordar aquí la performance con que el grupo pop La Orquesta Mondragón interpretaba su canción "Caperucita feroz" — con letra del poeta Luis Alberto de Cuenca-, y que concluía con el desenmascaramiento de la afectada "Caperucita" que interpretaba el estribillo, cuando el cantante Javier Gurruchaga le arrebataba la peluca y ponía al descubierto que la equívoca niña (bajo un disfraz grotesco que más bien le daba un aire entre femme fatale y señora burguesa) era, en realidad, Popotxo Ayestarán, otro de los integrantes del grupo. Así, la canción daba una vuelta de tuerca al cuento, ligando el travestismo a Caperucita (que termina por no ser más que un disfraz, una máscara, algo muy acorde al a los planteamientos con que el autor de la letra aborda los mitos en su obra ${ }^{11}$ ).

Varias de estas recreaciones intermediales surgidas en la escena política española reciente parten de un elemento relativamente marginal en el cuento, como es la abuela. Es el caso del ejemplo que analizaremos ahora (FIGURA 11). La escena elegida sigue siendo la del encuentro en la cama entre la niña y la falsa abuela, pero a la suplantación se añade como motivación fundamental la edad. La abuela/lobo se identifica con Manuela Carmena, jueza y alcaldesa de Madrid por Ahora Madrid, coalición de izquierda en la que se integraba Podemos. Carmena contaba 71 años cuando ganó a las elecciones municipales de 2015, y a lo largo de su mandato aseguró que valoraba no volver a presentarse al término de su mandato. Pero en 2019 sí se presentó, aunque de manera independiente, sin asociarse al partido liderado por Pablo Iglesias, Podemos. En su nueva formación, llamada "Más Madrid", se integraron destacados miembros de Podemos, como Íñigo Errejón, lo que algunos interpretaron como

11 El vídeo de una de las performances de la canción en RTVE puede verse en la plataforma YouTube: https://www.youtube.com/watch?v=ife23FDNxow. 
una traición política y personal a Iglesias. En la viñeta, firmada por Tomás Serrano ${ }^{12}$ y aparecida en el diario digital de corte liberalista El Español (18 de enero, 2019), una abuela descomunal y verdaderamente feroz está a punto de engullir a un lobo disminuido y de aspecto manso, en el que se adivinan sin dificultad los rasgos de Pablo Iglesias. Junto a la abuela, como Caperucita, reconocemos los rasgos aniñados de Íñigo Errejón. La viñeta ilustra de manera elocuente el texto firmado por Alberto D. Prieto, más opinión que noticia, encabezado por el título "Y la abuelita se comió al lobo: Carmena se queda con la izquierda madrileña" y que, desde su particular óptica, afirma "la inocente abuelita se ha tragado sin piedad al lobo. Al jefe de la manada".

Un segundo conjunto lo forman, como adelanté, microhistorias iconotextuales cuyo trasfondo ideológico podríamos calificar como feminista, pero que responden a una motivación contextual muy concreta. No estamos ya ante esos ejemplos mencionados al inicio de este artículo, tan abundantes en la Red y en los mass media en general, donde el personaje de Caperucita servía para imprimir al cuento un giro irónico, feminista en términos lasos, sin complejidad en su formulación y sin un anclaje particular en acontecimientos de la actualidad. Antes bien, nos referimos a los titulares, viñetas y memes que recurren al intertexto de Caperucita para denunciar un suceso concreto: el conocido como "Caso de La Manada". Convendrá resumir brevemente los hechos, que han trascendido la actualidad española y encontrado amplio eco en medios internacionales. Todo ocurrió en plena celebración del inicio de las fiestas de San Fermín, en la ciudad de Pamplona. Durante la madrugada del 7 de julio de 2016, una joven de 18 años y un grupo de hombres de entre 25 y 28 años entablaron conversación y entraron juntos en el portal de una casa. Una vez allí, ella fue sometida a una violación múltiple que además fue parcialmente grabada en vídeo. Los violadores huyeron robando el teléfono móvil de la víctima. Esta fue socorrida por algunos viandantes que la acompañan a un centro médico; tras el reconocimiento puso una denuncia y pocas horas después fueron detenidos José Ángel Prenda Martínez, Alfonso Cabezuelo Entrena, Antonio Manuel Guerrero Escudero, Jesús Escudero Domínguez y Ángel Boza Florido. Prácticamente desde el principio fueron identificados en la prensa como "La Manada". El apelativo procede del nombre del grupo de la red social WhatsApp del que formaban parte cuatro de los cinco culpables, junto con otros amigos (el nombre era, más exactamente, "The manada"). Ciertos mensajes intercambiados por algunos de los acusados insistían en el uso perverso del lobo como tótem identificatorio del grupo, ${ }^{13} \mathrm{y}$ dos de los violadores llevaban tatuajes alusivos a dicho animal —uno de ellos, con el motto "el poder del lobo reside en la manada"-.

El caso puso de manifiesto que la violación en grupo es un delito más común, probablemente, de lo que creíamos, y la prensa y la sociedad pasaron a designar "manada" a todos los grupos de violadores. Pero esta denominación confluye con el sintagma "síndrome de Caperucita", ya en uso con anterioridad a este caso para hacer referencia no solo al miedo

\footnotetext{
${ }^{12}$ El humorista gráfico Tomás Serrano, nacido en León y residente en Salamanca, fue galardonado en 2011 con el World Press Cartoon.

${ }^{13}$ El Juzgado de instrucción número 4 de Pamplona intervino las conversaciones mantenidas por los acusados en distintos grupos de WhatsApp, algunas de las cuales fueron divulgadas en distintos medios de comunicación. En un grupo llamado "Veranito", Antonio Manuel Guerrero proponía a Ángel Boza Florido sumarle al grupo "The Manada", y este declinaba la invitación alegando "Jaja, no que aún no he hecho méritos para ser un lobo"; a lo que Guerrero respondía: "Estas vacaciones son la prueba de fuego para ser un lobo" (Morales y Conde, 2016).
} 
de la mujer —especialmente joven — que camina sola por la calle, máxime si es de noche, sino sobre todo al hecho cultural de que tal situación deba ser aceptada por las mujeres como peligrosa. La gran cantidad de memes que recrean, con un mensaje feminista más o menos definido, a la niña vestida de rojo y el lobo, pueden haber actuado como sustrato popular (sirvan como ejemplo las FIGURAS 12 y 13), pero los que ahora veremos son mucho más concretos y claros en su alusión a este suceso de actualidad.

En el caso que ahora nos ocupa, la noticia de la violación, pero muy especialmente el polémico desarrollo judicial del caso, suscitaron una respuesta social en la que actuaba como subtexto el cuento de Caperucita roja (no me refiero ahora a ninguna de sus versiones literarias en particular, sino más bien a la constelación de motivos que dicho título invoca en cualquier receptor), y como motivos o mitemas recurrentes el lobo, la manada y la joven indefensa ataviada de la sempiterna capa roja. No en todos los casos los tres elementos aparecerán explícitamente expresados, pero sí podemos decir que la aparición de alguno de ellos invoca en el receptor a los otros. En algunos casos, se introducirán, como veremos, otros motivos que en realidad parten de los tres esenciales; en estos casos, la desviación aportará una lectura políticamente semantizada.

En las viñetas que a continuación veremos puede apreciarse que el trasfondo es la identificación del lobo como encarnación de la sexualidad y, específicamente, la violación. El lobo, como símbolo, concilia significados diversos, positivos unos y negativos otros (Chevalier, 1986: 652-654). Entre los segundos, la ferocidad y el mal, que en ocasiones puede asociarse con el sexo (en latín, el femenino lupa significa también "prostituta"), y particularmente con la violencia sexual, a partir de una identificación entre coito, violencia e ingesta que continúa viva en nuestro imaginario (pensemos en una expresión como “depredador sexual”). Más específicamente, González Marín (2005: 72) ha identificado tradiciones grecolatinas en las que aparecían unidos lobo y rapto, a veces aludiendo al matrimonio (que sería la forma "civilizada" del rapto ancestral). Pero en este caso se suman la explícita identificación de varios miembros del grupo con este animal, identificación que además se basaba en su actuación en grupo, y se expresaba mediante rasgos distintivos como los tatuajes o el nombre del grupo de WhatsApp. En su puesta en escena, los jóvenes que participaron en la violación están replicando - de manera perversa y grotesca, si se quiere, pero no por ello menos real ni funcional- elementos tradicionalmente reconocidos como configuradores de comunidad, tales como el tatuaje, el tótem y el endónimo. Además, veremos que a esa base semántica (lobo-violación) se suman otros mensajes que también están latentes en el mito, y en los que merece la pena detenerse.

La FIGURA 14 muestra un meme encontrado en la web little-revolutions.com, dedicada a la coeducación; se combinan, con una esquemática imagen de la niña de rojo acechada por lobos, tres lemas. Uno, "No es no", es bien conocido como reivindicación feminista de libertad sexual; otro, "Cambia el cuento", alude a la reformulación de los cuentos tradicionales y, en general, a la transformación de los comportamientos sociales vinculados al género; el tercero, en fin, es nuevo y responde más claramente al suceso que motivó esta reacción: "No fue un lobo, fue una manada".

En las manifestaciones de apoyo a la víctima se repitieron lemas como "La manada somos nosotras" o "Aullaremos en manada" (FIGURAS 15 y 16), que se apropiaban, 
subvirtiendo su sentido, del nombre y el tótem de los criminales. ${ }^{14}$ No faltaron algunas críticas que rechazaban esa identificación, como la del poeta y periodista Sergio C. Fanjul, quien el 18 de noviembre de 2017 hacía notar en la red social Facebook: "el lema de la mani era desafortunado: La Manada somos nosotras (de qué valores de La Manada se supone que debemos apropiarnos?)". La refutación de Fanjul es plausible, pero pasa por alto que también el grupo de violadores se había apropiado del término manada y del símbolo del lobo, dándoles un sentido interesado que, por ejemplo, a los animalistas parecerá deshonesto. Convendría tal vez recordar, llegados a este punto de lanzamiento de mitemas, que el mito es inocente de los usos que queramos hacer de él.

El meme del ilustrador y humorista gráfico Ferrán Martín (FIGURA 17) se publicó en Tumblr el 16 de noviembre de 2017. Presenta a Caperucita en medio de un bosque tenebroso, huyendo de cinco lobos que la persiguen (un cartel aclara: "Manada"). La innovación respecto del cuento es pequeña y obvia (en lugar de un lobo, cinco), y digamos que está asumida por los lectores, que probablemente habían visto ya otras viñetas o titulares que recurrían al cuento tradicional para hablar de este suceso. La mayor innovación se da respecto de esa traslación sencilla del cuento al caso, al introducir un nuevo antagonista, representado por tres hienas que esperan a Caperucita cortándole la huida y sonriendo. Un cartel aclara: "Jauría mediática", denunciando la divulgación de datos de la víctima en algunos medios durante el proceso. La propia Fiscalía de la Comunidad Foral de Navarra, en su Memoria sobre el Ejercicio 2018, recoge que el caso recibió un trato informativo pernicioso "con publicación de aspectos y datos personales de la misma, dando lugar a una clara victimización secundaria totalmente innecesaria" (2018: 171). El meme denuncia este proceder, que no solo vulnera la protección de datos y el derecho a la intimidad y el anonimato de la víctima, sino que parece apoyarse en la connivencia o al menos la tolerancia de parte de la opinión pública con la violación. Pero lo que aquí se trata de elucidar, más que la oportunidad de este sencillo meme, es el componente de mito que subyace en él. La jauría representaría en estas viñetas aquello que, siendo en origen salvaje, ha logrado instalarse en la domesticidad, que le sirve de coartada, y gracias a la cual actúa y emite sus juicios desde el ámbito de la razón y el poder, pero que dista de haberse desprendido de su naturaleza bestial.

El diario digital El Español publicó el 27 de abril de 2018 la viñeta de Tomás Serrano (FIGURA 18). En ella vemos a cinco lobos (más dos sombras proyectadas sobre la pared) cercando a una oveja contra la pared. El texto — pronunciado, se entiende, por el grupo de depredadores - reza: "Solo será abuso porque no va a ser necesaria la violencia, ¿verdad, ovejita?". La fecha de publicación coincide con el anuncio de la fiscalía de recurrir la sentencia de la Audiencia Provincial de Navarra — que, recordemos, solo encontró abuso sexual continuado, pero no agresión- La viñeta, que incide sobre la violencia implícita en la superioridad numérica y de fuerzas, no recurre, de hecho, a una intertextualidad con el cuento de Caperucita (la víctima es una oveja), pero está claro que el lobo como depredador real (de ovejas) propicia rápidamente su lectura simbólica, de la que deriva el cuento, bien interiorizado en el imaginario popular como demuestran los memes seleccionados. El meme alude a uno de los detalles más espinosos del desarrollo judicial del caso: la distinción entre

14 Basta buscar en Google "La manada somos nosotras" para encontrar numerosos testimonios de las manifestaciones que con ocasión de la noticia del suceso y de la sentencia emplearon dicho lema. 
los delitos de "agresión sexual", que comprende todo acto sexual sin consentimiento de la víctima, los que involucran violencia o intimidación (Código Penal, art. 178), y "abuso sexual" (Código Penal, art. 181 y 182). En este caso, la sentencia inicialmente emitida por la Audiencia Provincial de Navarra encontró abuso, pero no agresión; el Tribunal Superior de Justicia de Navarra ratificó el delito de abuso (STSJ Navarra 000038/2018 de 20 de marzo). Pero, recurrida nuevamente la sentencia, el Tribunal Supremo sí consideró que había agresión sexual con intimidación, revocando las dos sentencias anteriores y elevando la pena de los cinco acusados a 15 años de prisión (STS 396/2019 de 21 de junio).

La viñeta de Javi Salado (FIGURA 19), se publica originalmente en La Tribuna de Toledo, pero encuentra mayor eco al ser reproducida en el Huffington Post y circular ampliamente en las redes sociales de este medio. Bajo el título "La Manada anda suelta", muestra a Caperucita tratando de ocultarse, asustada, en su cama, mientras la voz de un personaje fuera de escena (la madre, descodifica el lector) pregunta si no va a visitar a su abuelita (activando el conocimiento intertextual previo); la respuesta de la niña oculta tras la manta es "Ya no". La explicación la encontramos en el titular del periódico que yace a los pies de la cama, y que Caperucita, entendemos, acaba de leer: "Libertad provisional para los miembros de La Manada". La fecha de publicación (23 de junio de 2018) es un día posterior a la fecha en que los cinco miembros accedieron a la libertad bajo fianza de 6000 euros, por no haber aún sentencia firme y estimar la Audiencia Provincial de Navarra que no se cumplían los criterios merecedores de prisión preventiva.

La FIGURA 20 corresponde a una estampa de Manel Fontdevila publicada en El Diario; en el contexto original de la web se acompaña del título "Eran violadores". Este se comprende mejor si sabemos que el 21 de junio de 2019 — día en que está fechada la viñeta- el Tribunal Supremo revocó la sentencia anteriormente dada por el Tribunal Superior de Justicia de Navarra, por considerar que sí hubo un delito continuado de violación, y no únicamente abusos sexuales. La intertextualidad del meme con el cuento se difumina: la protagonista es bien reconocible, pero todo elemento de la narración (camino, bosque, cestita, abuela, etc.) desaparece, a excepción del antagonista, multiplicado en cinco lobos: uno de ellos está encerrado en una jaula; los otros cuatro, encaramados a la jaula, aparecen vestidos con una indumentaria humana (un traje) sobre el que llevan una piel de cordero, mientras gritan a la mujer: “¡Y luego dirán que la justicia es patriarcal!”, “¡Felicidades! ¡Ya puedes estar contenta!”, “ ¡Como siempre, la mujer gana!”, “ ¡Se dice «gracias»!”. Para Fontdevila, los jueces castigan al criminal (enjaulado), pero lejos de amparar a la víctima imparten una justicia insuficiente, machista, y lo subrayan con sus comentarios. Los cuatro aparecen ataviados con una vestimenta generalmente identificada como masculina, ${ }^{15}$ y además formal, en cierto modo un signo de prestigio; sobre ella, la piel de cordero traslada al plano visual la expresión popular "ser un lobo con piel de cordero" (que no solo alude a la peligrosidad del carnívoro frente al herbívoro, paradigma de la inocencia, sino que también replica la oposición salvaje/doméstico subyacente en el corazón mítico del cuento). Al margen de la sátira de la viñeta, me parece sumamente interesante reparar en que - de nuevo- el sentido descansa sobre la oposición entre lo que la sociedad proscribe (lo salvaje, lo criminal) y lo que

\footnotetext{
${ }^{15} \mathrm{~A}$ lo largo de su recorrido judicial, el caso pasó por un total de catorce jueces, de los cuales once eran varones $\mathrm{y}$ tres mujeres.
} 
se considera aceptable, civilizado y respetable (traje, representantes de la justicia, piel de cordero).

Ya Julio Caro Baroja nos advertía que las distinciones teóricas entre cuento y mito no reflejan las frecuentes recategorizaciones, y la posibilidad de que un relato que recibimos como cuento participe también del mito (Caro Baroja-Temprano, 1985: 114). La misma Caperucita que aleccionó — deleitándolas - a las jóvenes cortesanas de la Francia del siglo XVII, adquirió un sesgo antifrancés en Tieck o los hermanos Grimm, y fue más tarde vehículo de ideas nazis y también antinazis. Si ha podido hacerlo es en virtud de una asombrosa capacidad para resemantizarse sin perder lo que hace el cuento reconocible. Ni siquiera es necesario que todos los elementos de las versiones más conocidas estén presentes: alguno de ellos es, por sí mismo, suficiente, funcionando en ese sentido como un mitema. El autor puede actuar movido por el deseo de establecer un juego artístico de decodificación y complicidad con el lector, pero el fenómeno va más allá de la mera intertextualidad. Pues cuando incluso en medios populares, de gran circulación y escasa canonicidad, el cuento se carga de nuevos significados a fin de expresar preocupaciones que en un determinado momento resultan apremiantes, es porque estamos ante un relato esencial, etiológico, cuyos mitemas persisten, irreductibles, listos para responder a nuevas zozobras.

En los ejemplos que hemos podido ver a lo largo de este trabajo, Caperucita puede aparecer como motivo erótico (en virtud de una sexualización de su indumentaria, de su edad púber y de su encuentro con el lobo) o como emblema de la lucha feminista (interpretando dicho encuentro como una violación); incluso, como ha habido ocasión de observar, ambos mensajes pueden darse en la misma obra. Otro conjunto lo conforman las alusiones en clave política, en su mayoría motivadas por la polisemia del adjetivo rojo, y que, en función de la actualidad del momento puede explotar humorísticamente otros elementos del relato, como la cestita o la abuela. Mucho menos frecuente es que la atención se centre en la figura del lobo (el ejemplo que hemos podido ver lo hace al hilo de la proliferación del sintagma "lobo solitario"). Finalmente, un conjunto sumamente interesante es el de viñetas y memes surgidos a partir del suceso conocido como "Caso de la Manada": el desarrollo de la investigación y el procedimiento judicial dio pie a que se focalizase no solamente — como ya es habitual — la violencia del ataque del lobo (en este caso, los cinco lobos), sino también un mitema presente en el cuento pero generalmente menos atendido, como es la oposición entre lo salvaje y lo civilizado, que aquí sirvió para que se plantease la tolerancia de la ley —o de su aplicacióncon los criminales.

\section{Bibliografía}

AA.VV. (2011): Extravío 6. Monográfico "El cuento de nunca acabar. Escrituras y reescrituras de cuentos tradicionales".

BACCHILEGA, Cristina (1997): Postmodern Fairy Tales: Gender and Narrative Strategies. Philadelphia (PA), University of Pennsylvania Press. DOI: https://doi.org/10.9783/9780812200638

--- (2013): Fairytales transformed? Twenty-First Century Adaptations and the Politics of wonder. Detroit (MI), Wayne State University Press. 
BECKETT, Sandra L. (2002): Recycling Red Riding Hood. New York—London, Routledge / Detroit (MI), Wayne State University Press. DOI: https://doi.org/10.4324/9780203951330

--- (2008): Red Riding Hood for All Ages. A Fairy-Tale Icon in Cross-Cultural Contexts. Detroit (MI): Wayne State University Press.

BETTELHEIM, Bruno (1994): Psicoanálisis de los cuentos de hadas. Trad. Silvia Furió. Barcelona, Grijalbo-Mondadori.

BUXTON, Richard (1994): Imaginary Greece. The Contexts of Mythology. Cambridge, CUP.

CARO BAROJA, Julio-TEMPRANO, Emilio (1985): Disquisiciones antropológicas. Madrid, Istmo.

CHEVALIER, Jean-GHEERBRANT, Alain (1986) [1982]: Diccionario de los símbolos. Trad. Manuel Silvar y Arturo Rodríguez. Barcelona, Herder.

DUNDES, Alan (ed.) (1989): Little Red Riding Hood: A Casebook. Wisconsin, University of Wisconsin Press.

ELIADE, Mircea (1991): Mito y realidad. Trad. Luis Gil. Barcelona, Labor.

ESPAÑA. MINISTERIO DE JUSTICIA (2019): Código Penal y legislación complementaria. Última modificación: 4 de marzo de 2019. Disponible en: https://www.boe.es/legislacion/codigos/codigo.php?id=038_Codigo_Penal_y_legislaci on complementaria\&modo=1.

ESPAÑA. TRIBUNAL SUPREMO (Sala de lo Penal) (2019): Recurso de Casación núm. 396/2019 de 21 de junio de 2019.

FISCALÍA DE LA COMUNIDAD FORAL DE NAVARRA (2019): Memoria 2019 (Ejercicio 2018). Disponible en: https://www.fiscal.es/documents/20142/144437/Memoria+2019+del+Fiscal+Superior +de+Navarra.pdf/00d0326e-f834-5f8f-ec96e41a74d1e46b?version $=1.1 \&$ previewFileIndex $=$.

GARCÍA PUENTE, María (2014): Érase de nuevo una princesa: las reescrituras feministas de cuentos de hadas de la España del Tercer Milenio. Tesis doctoral defendida en la Universidad de Kansas, 2014. Disponible en: https://kuscholarworks.ku.edu/bitstream/handle/1808/23948/GarcaPuente_ku_0099D 13655 DATA_1.pdf? sequence=1.

GONZÁlEZ MARÍN, Susana (2005): ¿Existía Caperucita Roja antes de Perrault? Salamanca, Universidad de Salamanca.

MARTÍNEZ DEYROS, María (2019): “«i¿Perdona?! Con el cuento a otra...»: disrupciones y continuidades del cuento tradicional en la microficción hispánica". En María Martínez Deyros - Carmen Morán Rodríguez (eds.): Pasado, presente y futuro del microrrelato hispánico. Berlin, Peter Lang: 83-98.

MORALES, Jesús - CONDE, Enrique (2016): "Los aullidos de la manada: «Este viaje es la prueba de fuego para ser un lobo»". Noticias de Gipuzkoa (16 de octubre de 2016). Disponible en: https://www.noticiasdegipuzkoa.eus/2016/10/16/sociedad/los-aullidosde-la-manada-este-viaje-es-la-prueba-de-fuego-para-ser-un-lobo

[Consulta: 9/11/2019]. 
MORÁN RODRÍGUEZ, Carmen (2018): "Reescrituras actuales de cuentos tradicionales". En Eva Álvarez Ramos-Carmen Morán Rodríguez (eds.): Cuento actual y cultura popular. La ficción breve española y la cultura popular, de la oralidad a la web 2.0. Valladolid-Nueva York, Cátedra Miguel Delibes_-Universidad de Valladolid: 4569.

--- [En prensa]: "En el bosque hay palabras / que no dejan de oírse / para quien sabe oír: sobre bosques y lobos, con Luis Díaz Viana". En Javier Dámaso Blanco (ed.): "Salvajes" de acá y de allá: memoria y relato de nos-otros. En torno a los trabajos de Luis Díaz Viana. Madrid: C.S.I.C.

NAVARRA. AUDIENCIA PROVINCIAL (Sección 2a) (2018): Sentencia núm. 000038/2018 de 20 de marzo. Disponible en: https://cdn.20m.es/adj/2018/04/26/3934.pdf.

NOGUEROL JIMÉNEZ, Francisca (2000): "Para leer con los brazos en alto: Ana M. ${ }^{\text {a }}$ Shua y sus versiones de los cuentos de hadas". Revista Interamericana de Bibliografia 13.4: $142-58$.

--- (2001): "La metamorfosis de Caperucita". En Sonia Mattalía (ed.): Aún y más allá: mujeres y discursos. Caracas, Escultura: 113-22.

ORENSTEIN, Catherine (2003): Caperucita al desnudo. Trad. Luis Noriega. Barcelona, Ares y Mares.

RITZ, Hans (2000): Die Geschichte vom Rotkappchen. Gottingen: Muriverlag.

ZIOLKOWSKI, Jan M. (1992): “A Fairy Tale from before Fairy Tales: Egbert of Liège's «De puella a lupellis seruata» and the Medieval Background of «Little Red Riding Hood»". Speculum 67: 549-75. DOI: https://doi.org/10.2307/2863656

ZIPES, Jack (1983): Trials and Tribulations of Little Red Riding Hood. New York-London, Routledge. DOI: https://doi.org/10.4324/9780203700433

--- (1984): Don't bet on the Prince. Contemporary Feminist Fairy Tales in North America and England. Aldershot: Gower. DOI: https://doi.org/10.4324/9780203825792

C Carmen Morán Rodríguez

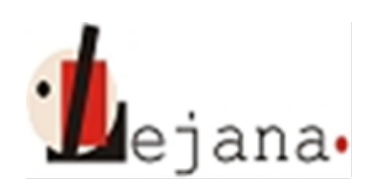

http://ojs.elte.hu/index.php/lejana

Universidad Eötvös Loránd, Departamento de Estudios Hispánicos

1088 Budapest, Múzeum krt. 4/C 


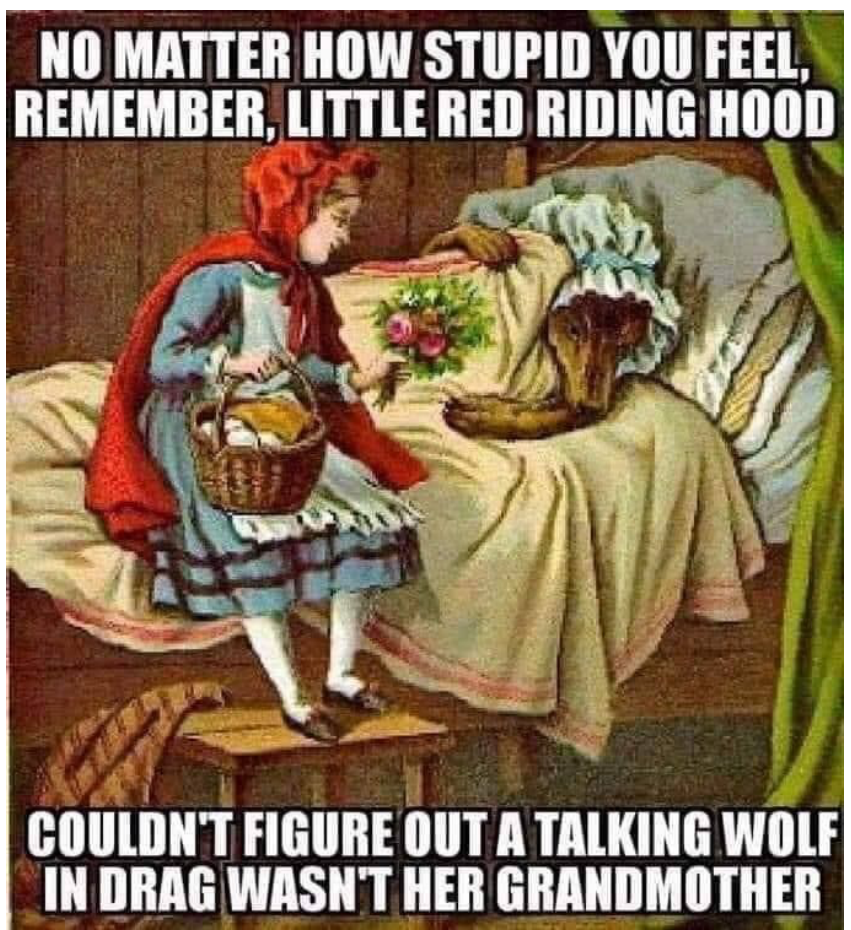

FIGURA 1

Anónimo. Meme de amplia circulación en la Web. Disponible, entre otros muchos lugares, en: https://me.me/i/no-matter-how-stupid-you-feel-remember-little-red-riding-

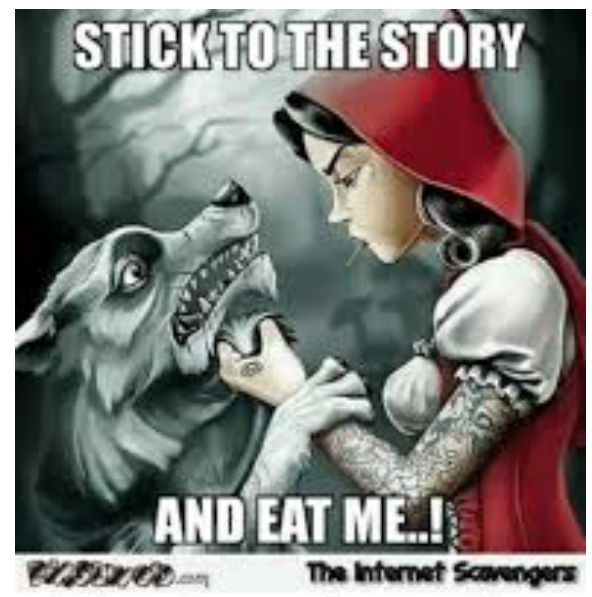

Stick to the story funny adult little red riding hood meme | PMSLweb

FIGURA 2

Anónimo. Meme en la Web. Disponible en: http://www.pmslweb.com/the-blog/nsfw-adult-humoryou-have-a-dirty-mind/28-stick-to-the-story-funny-adult-little-red-riding-hood-meme/ 


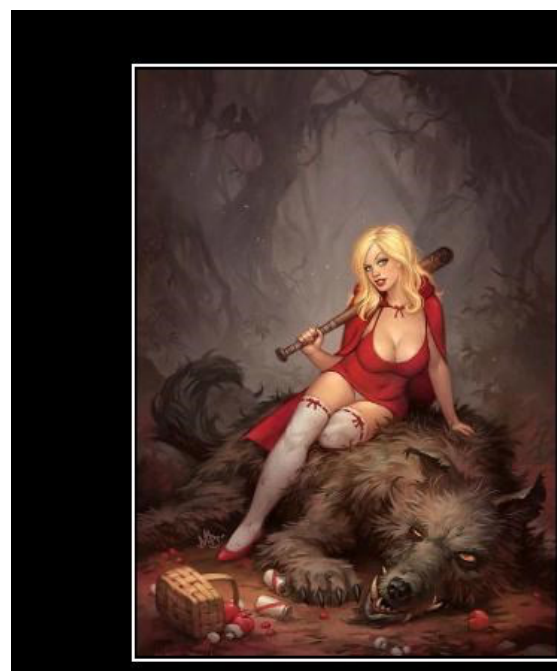

\section{LITTLE RED RIDING} HOOD

Not so little anymore and she's doing it just right

FIGURA 3

Anónimo. Meme en circulación en la Web. Disponible en: https://me.me/i/little-red-riding-hood-notso-little-anymore-and-shes-17098653

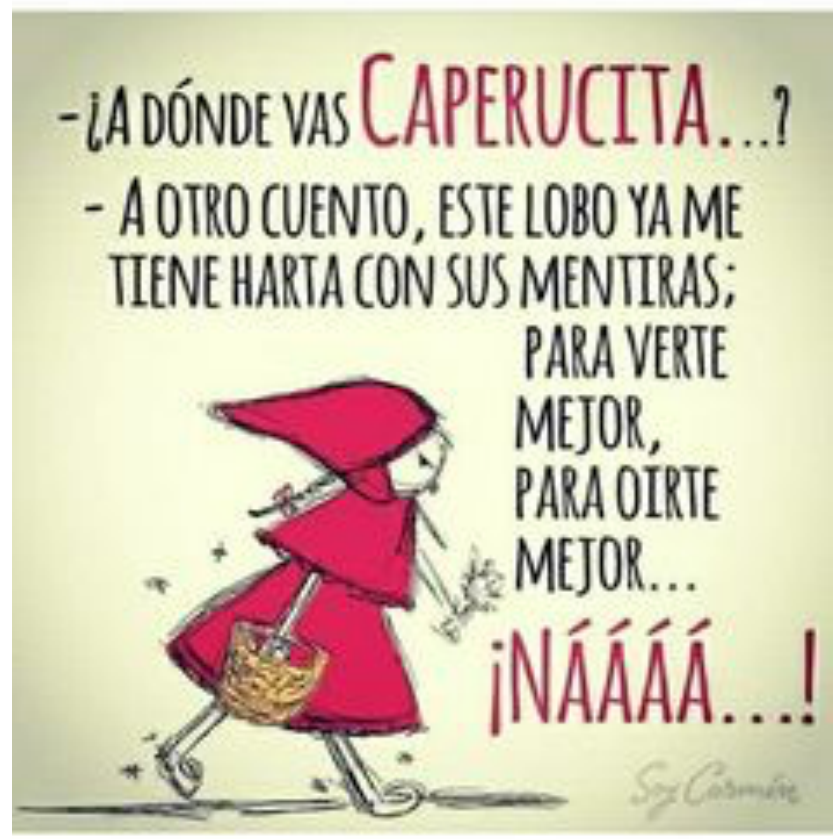

FIGURA 4

Meme en circulación en la Web. Existen variantes con diferente dibujo y tipografía Disponible en: https:/www.pinterest.es/pin/767371223985936538/ 


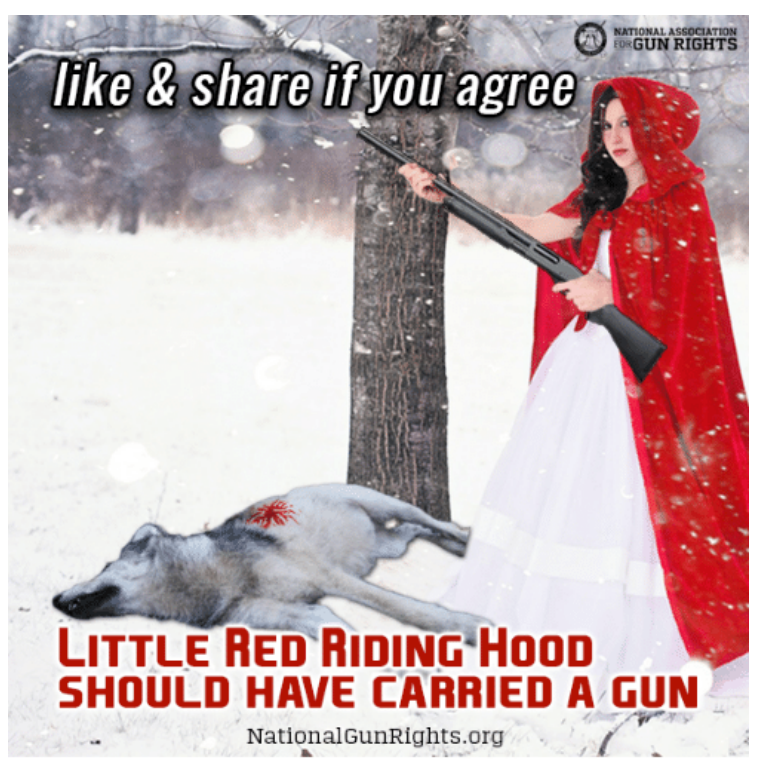

What do you think?

FIGURA 5

Meme o cartel anónimo para NationalGunRights.org. Disponible en: https://me.me/i/nationalassociation-forgun-rights-like-share-if-vou-agree-17829639

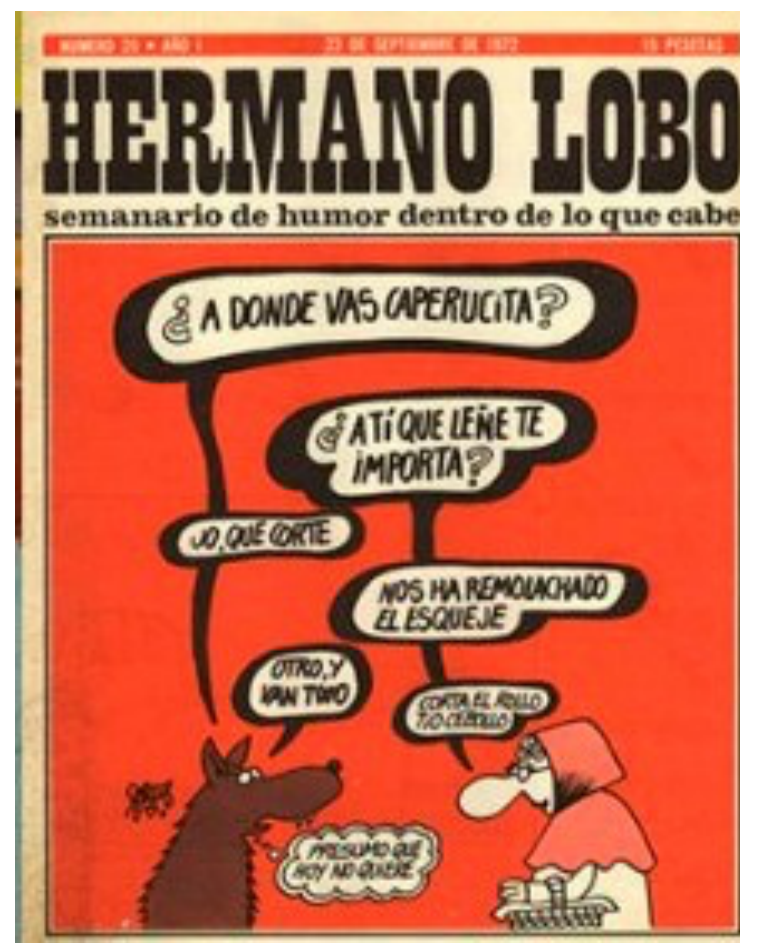

FIGURA 6

Antonio Fraguas, "Forges". Portada para Hermano Lobo, nº 20 (20 septiembre, 1072). 


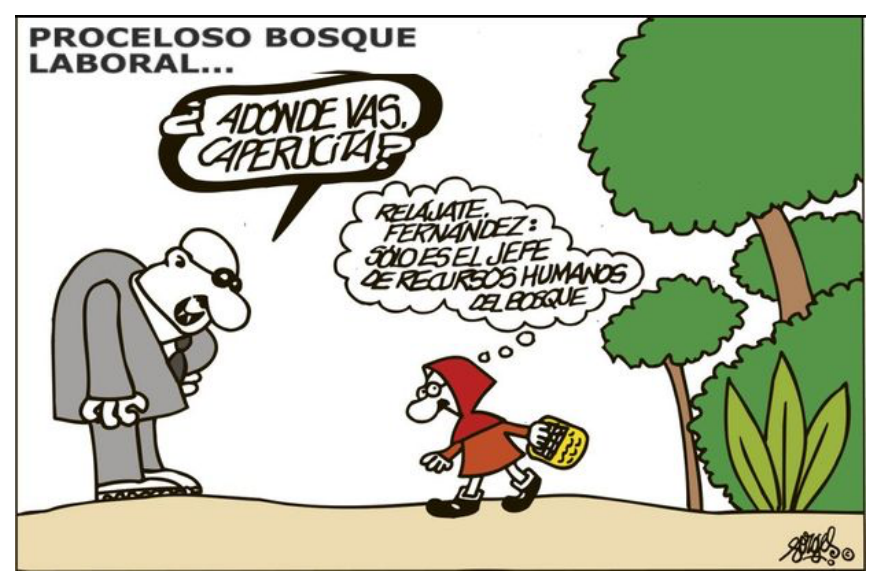

FIGURA 7

Antonio Fraguas, "Forges". "Proceloso bosque laboral", El País 2 julio 2008. Disponible en: http://cajondesastremisterioso.blogspot.com/2014/07/forges-proceloso-bosque-laboral-en-el.html

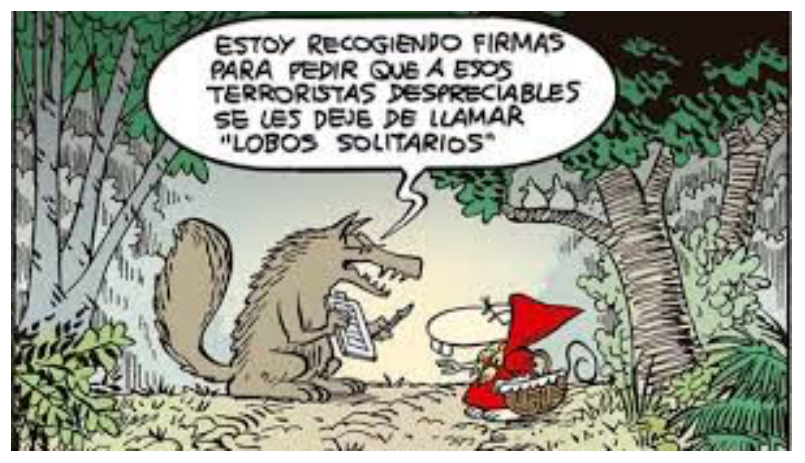

FIGURA 8.

J. M. Nieto, "En defensa del lobo". $A B C 21$ julio 2016. Disponible en: https://abcblogs.abc.es/fe-deratas/vinetas/jueves-21-de-julio.html

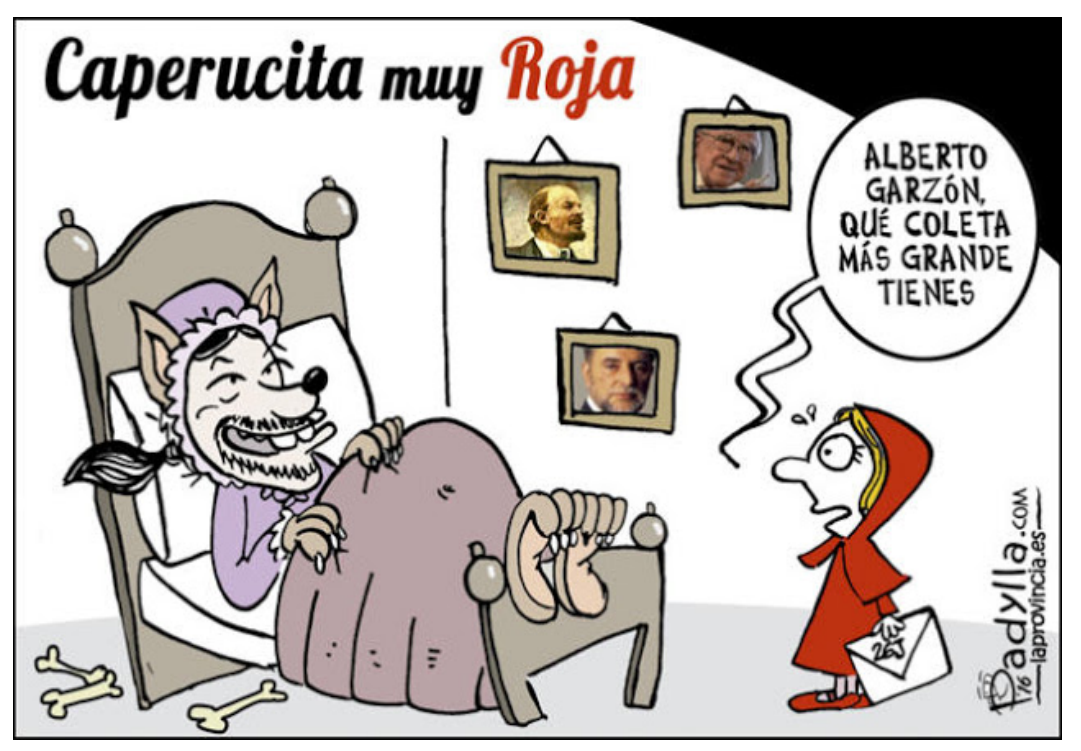

FIGURA 9.

Padylla, "Caperucita muy roja". 11 mayo 2016. Disponible en: http://blog.padylla.com/2016/05/caperucita-muy-roja.html 


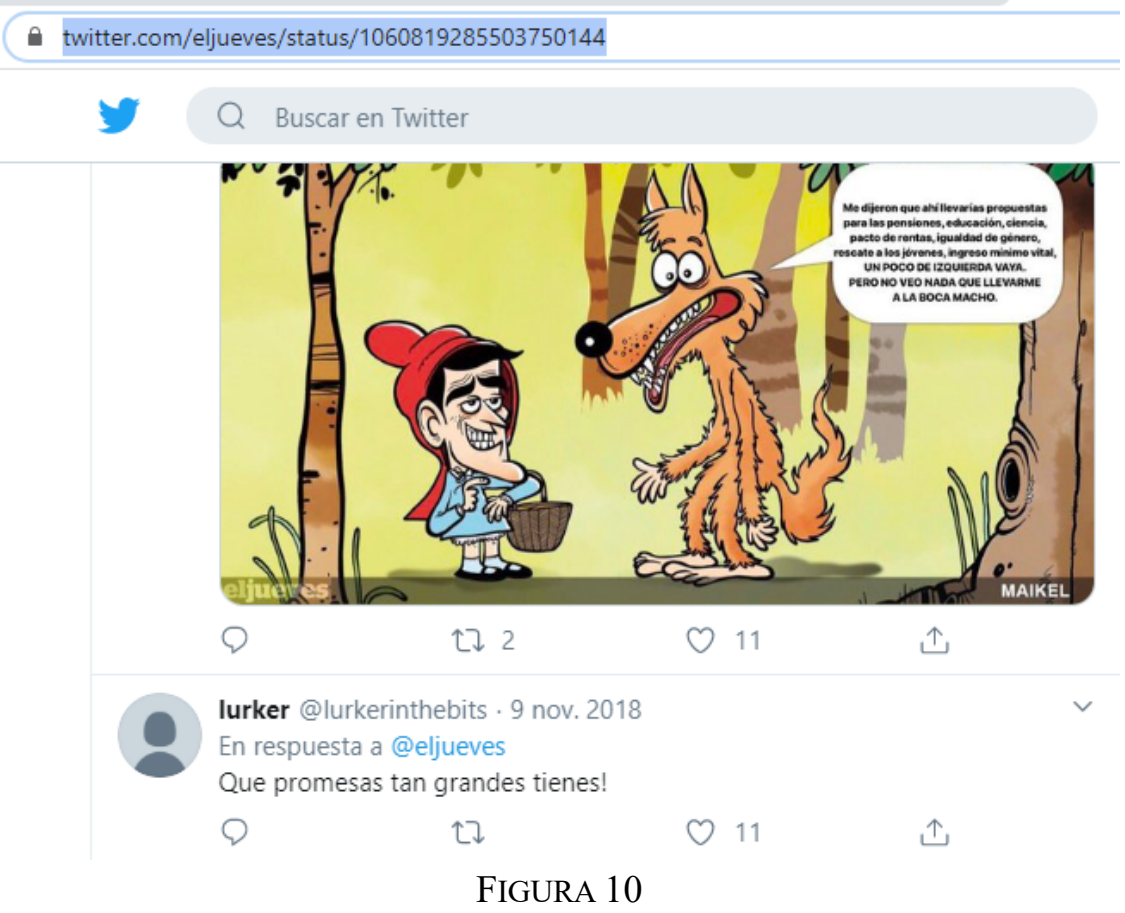

Maikel, Twitter de El Jueves, con texto de Marc LM (@mmaclopez), 9 noviembre 2018. Disponible en: https://twitter.com/eljueves/status/1060819285503750144

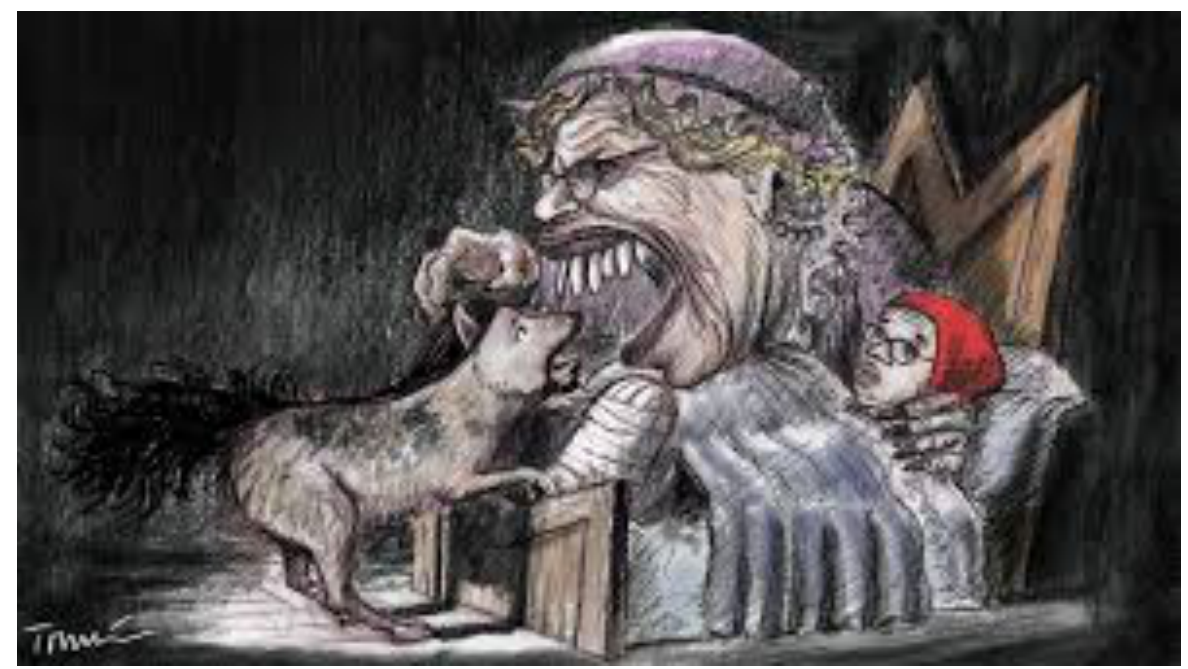

FIGURA 11

Tomás Serrano, viñeta para la columna de Alberto D. Prieto, "Y la abuelita se comió al lobo: Carmena se queda con la izquierda madrileña". El Español 18 enero, 2019 Disponible en:

https://www.elespanol.com/espana/politica/20190118/abuelita-comio-lobo-carmena-queda-izquierdamadrilena/369214454_0.html 


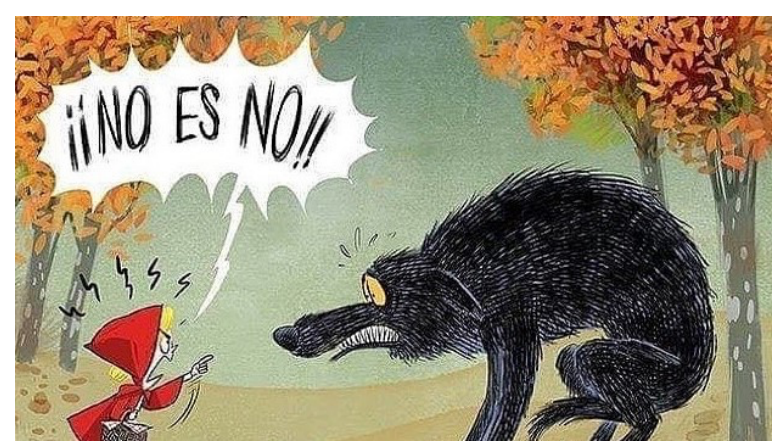

FIGURA 12

Meme de Santi Gutiérrez, fechado en 2018. Disponible en:

https://www.scoopnest.com/es/s/Santy\%20Gutierrez También reproducido como post en el perfil "Caperucita Roja" de Facebook, en un post del 20 de noviembre de 2019.

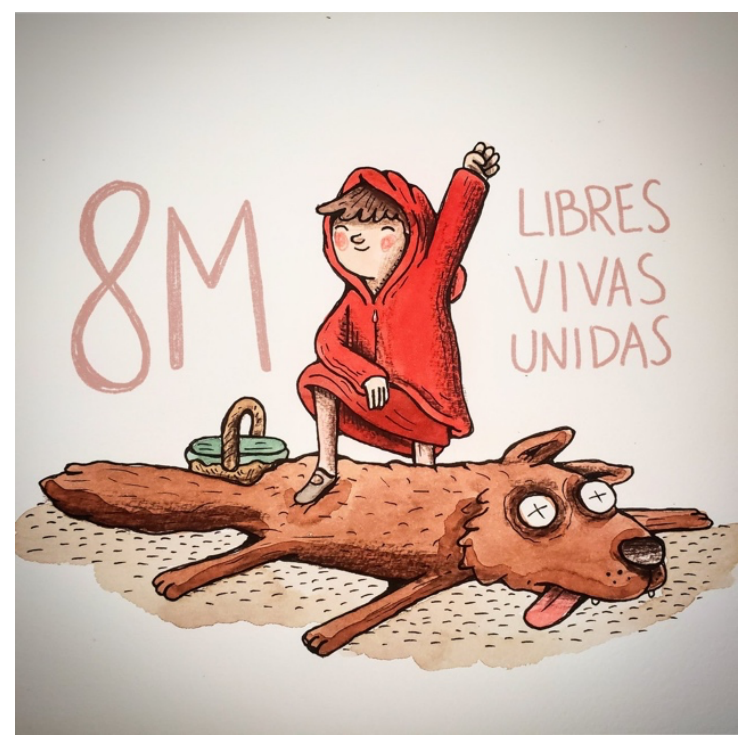

FIGURA 13

Ilustración de Alberto Montt, tuiteada por él (@albertomontt), 8 marzo de 2019. Disponible en: https://www.trendsmap.com/twitter/tweet/1103979797955383301

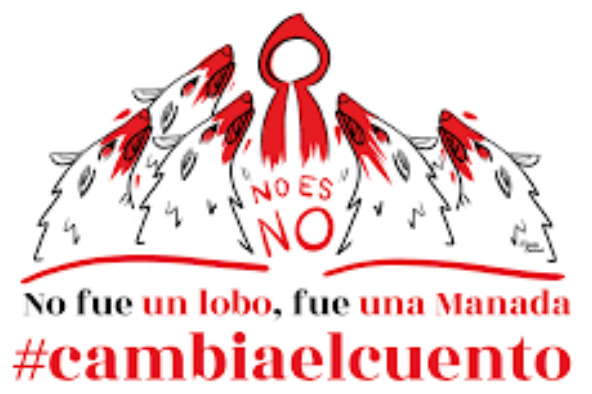

Utuerevolutions

\section{FIGURA 14}

Cartel o meme sin autoría (27 abril 2018). Disponible en: https://ittle-revolutions.com/no-era-1-loboera-una-manada-de-5/ 


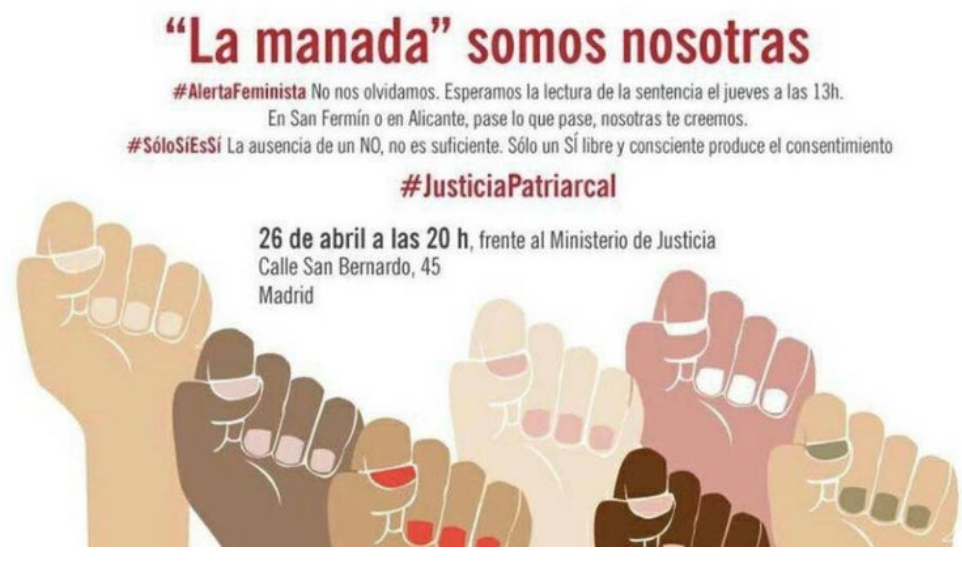

FIGURA 15

Fotografía de la convocatoria a la manifestación de protesta por la sentencia del Caso Manada. El

Confidencial (26 abril 2018). Disponible en: https://www.elconfidencial.com/espana/2018-04-

26/manifestacion-manada-juicio-sentencia-abuso-sexual-violacion_1555537/

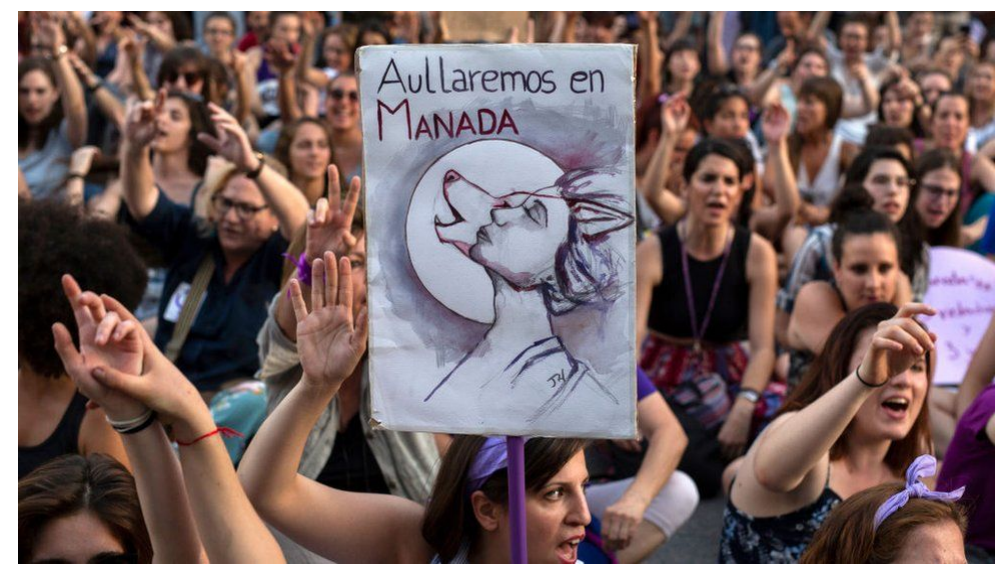

FIGURA 16

Imagen publicada en $B B C$ News (28 junio 2019). Disponible en: https://www.bbc.com/mundo/noticias-internacional-48806905

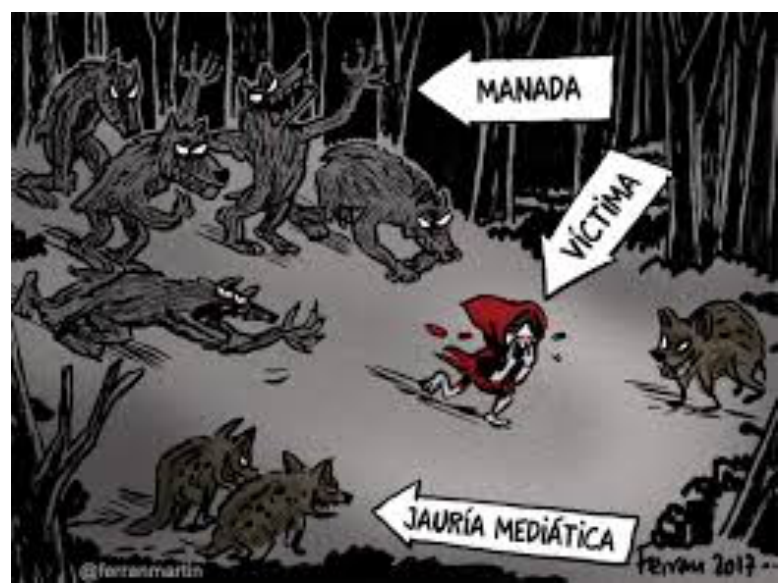

FIGURA 17 
Ferrán Martín, viñeta publicada en Tumblr (16 noviembre 2017). Disponible en: https://ferranhumor.tumblr.com/post/167550475244/manadas/amp

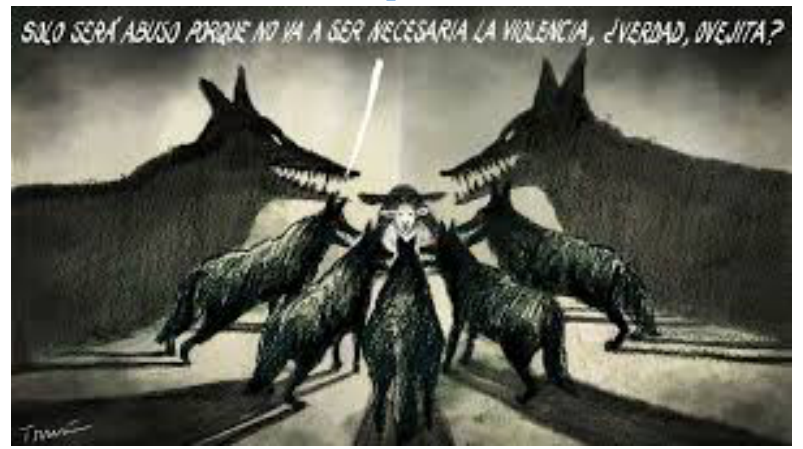

FIGURA 18

Tomás Serrano, viñeta publicada en El Español, 27 de abril de 2018. Ilustra el artículo de opinión "Una ley, cuatro juristas y tres posturas", firmado por Cruz Sánchez de Lara. Disponible en: https://www.elespanol.com/espana/20180429/ley-juristas-posturas/303589639 12.html

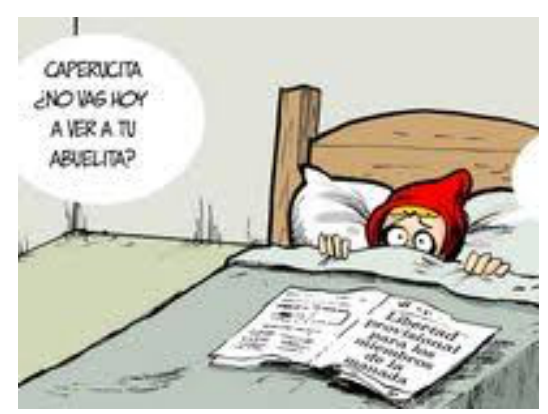

FIGURA 19

Javi Salado, "La manada anda suelta", The Huffington Post, 22 junio 2018. Disponible en: https://www.huffingtonpost.es/javi-salado/la-manada-anda-suelta a 23465457/

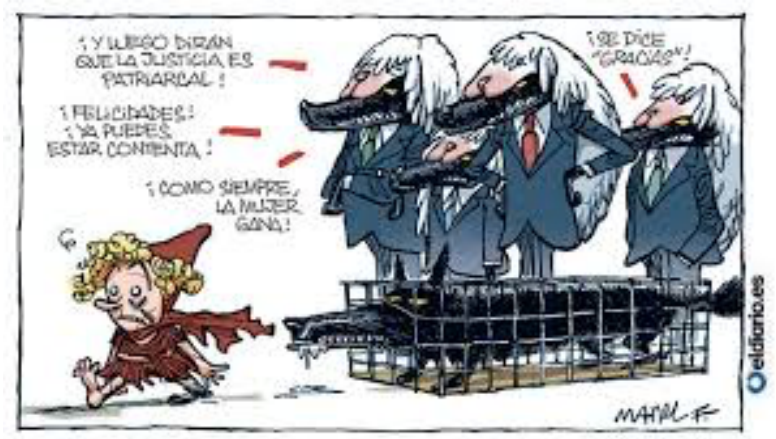

FIGURA 20

Manuel Fontdevila, "Eran violadores". El Diario, 21 junio 2019. Disponible en: https://www.eldiario.es/vinetas/violadores 10 912458746.html 